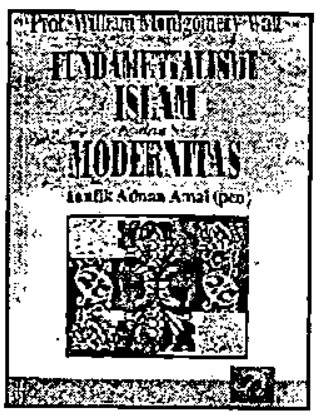

$\begin{array}{lll}\text { Judul } & : & \text { Islamic Fundamentalism and Modernity } \\ \text { Penulis } & : & \text { William Montgomery Watt } \\ \text { Penerjemah } & : & \text { Taufik Adnan Amal } \\ \text { Cetakan } & : & \text { Pertama, November } 1997 \\ \text { Edisi } & : & 1 \\ \text { Penerbit } & : & \text { PT. Raja Grafindo Persada, Jakarta } \\ & & \text { X. } 306 \mathrm{HIm} .18 \mathrm{~cm} \\ \text { ISBN } & : & 979-421-634-8\end{array}$

\title{
Fundamentalisme Islam dan Modernitas
}

T

ema utama tulisan Watt dalam bukunya yang berjudul "Fundametalisme Islam dan Modernitas" terjemahan Taufik Adnan Amal adalah, bahwa pemikiran para intelektual fundamentalis Islam dan sejumlah besar muslim awam masih dikuasai pandangan dunia standar tradisional Islam dan potret diri yang sesuai dengan kondisi kaum muslimin pada abad ke-7 di Mekah atau abad ke-9 di Bagdad. Menurut Watt (h.3) pijakan-pijakan utama pandangan dunia standar atau tradisional, telah terbentuk pada 950-an dan memperoleh bentuk pasti pada 1200-an. Setelah itu pandangan dunia tersebut tidak mengalami perubahan. Pandangan aliran-aliran sempalan yang awal sebagian besar telah diperas keluar dan hanya tersedia peluang kecil bagi pandangan-pandangan aliran baru untuk berkembang. Suatu gerakan seperti Wahhabi (muncul di Arabia Tengah pada abad ke-18 dan kini merupakan ajaran resmi kerajaan Saudi) meskipun dalam pengertian tertentu adalah baru, namun pada dasarnya merupakan penegasan kembali beberapa aspek pandangan dunia standar dalam suatu arah yang konservatif.

Pandangan dunia tradisional inilah yang menjadi keprihatinan Watt sehingga ia berusaha untuk menelaah akar permasalahan yang dihadapi dan prospek berbagai gerakan pembanuan di dunia Islam dewasa ini. Secara khusus, perhatian difokuskan pada fundamentalisme Islam (baik di kalangan Sunni maupun Syiah Imamiyah) dan hingga tertentu, liberalisme Islam, dalam kaitannya dengan pandangan dunia dan potret diri tradisional Islam.

Berbeda dengan kebanyakan karya orientalis yang "steril", karya Watt ini kaya dengan preskripsi tentang bagaimana seharusnya kaum muslimin masa kini berhadapan dengan kemoderenan sejarah. Di sinilah letak sisi kontroversial buku ini. la melihat prospek fundamentalisme Islam (terutama di kalangan Sunni) sangat suram 
dan tidak membawa harapan, kecuali gerakan ini menyeberang ke sisi liberalisme Islam, yang terutama tercermin dalam gagasangagasan Fazlur Rahman (1919-1988) dan Mohammed Akoun. Menurut Watt (h.147) potret diri tradisional Islam menyulitkan kaum muslimin menyesuaikan diri secara memadai dengan kehidupan di penghujung abad ke20. Selain itu juga menyulitkan negeri-negeri Islam memainkan peran dalam urusanurusan dunia yang dibenarkan oleh penduduk dan kekuatannya.

\section{Potret Diri Fundamentalisme Islam dan Modernitas}

Dalam kajian tentang aliran-aliran Islam, untuk pertama kalinya. Watt (h. 6) menyadari ketiadaan mutlak gagasan perkembangan. Dalam Islam tidak terdapat suatu rumusan kepercayaan resmi. $\mathrm{Hal}$ ini terjadi karena tidak ada badan yang diberi wewenang untuk menyusun suatu kepercayaan tertentu yang merupakan kepercayaan resmi seluruh umat Islam; tetapi dalam perumusan doktrin-doktrin kepercayaan tersebut telah tercipta suatu bidang kesepakatan tidak resmi yang luas (ijma).

Banyak sarjana muslim telah merumuskan doktrin-doktrin kepercayaan, yang oleh seorang pengamat barat modern di dalamnya ditemukan suatu proses perkembangan. Namun sarjana-sarjana muslim tradisional dalam masalah ini tidak mengakui perkembangan tersebut, bahkan sebaliknya menegaskan bahwa doktrin sejati yang lengkap telah ada sejak masa Muhammad. Demikian pula pengikut berbagai aliran sempalan dipandang sebagai orang-orang yang telah menerima pandangan-pandangan keliru. Dalam hal ini tidak disadari bahwa beberapa di antara aliran tersebut telah memberikan sumbangan penting kepada pemikiran kaum muslimin dalam masalahmasalah keagamaan. Namun terdapat berbagai bidang lainnya di samping teologi para pemikir muslim 'memperlihatkan ketiadaan konsepsi perkembangan. Mereka beranggapan bahwa sejak masa Muhammad umat manusia tidak berubah secara hakiki. Sekalipun mungkin terdapat perbedaan beberapa jenis karakter, tetapi tidak dapat dikatakan telah terjadi kemajuan atau perkembangan berarti dalam karakter manusia. Kebetulan sifat dasar manusia telah memberi pembenaran kepada para sarjana muslim untuk menegaskan fasilitas aturan-aturan dan hukum-hukum perilaku manusia yang dinyatakan di dalam Al-Qur'an dan Sunnah Nabi (h. 8). Dengan demikian pembaruan sosial adalah gagasan yang benar-benar tidak masuk akal bagi kaum muslimin yang berpikiran tradisional. Terlepas dari itu semua, padahal pengembangan asli syari'ah selama tiga abad pertama Islam dalam kenyataannya telah mengubah praktek suatu masyarakat yang pada mulanya relatif primitif menjadi suatu imperium yang berbudaya.

Namun dari pernyataan tersebut Watt (h. 9) lebih lanjut berpendapat bahwa masalah yang lebih mendasar adalah apakah kemajuan-kemajuan ilmu pengetahuan dan teknologi Barat khususnya yang dicapai selama dua abad terakhir telah mengubah sifat-sifat dasar manusia? Jawaban pertanyaan tersebut barangkali benar, sehingga telah mengaburkan pandangan sarjanasarjana muslim tradisional yang awalnya berasumsi tentang tidak berubahnya sifat dasar manusia. Konsekuensinya, sekalipun diakui bahwa sifat dasar manusia pada hakikatnya tidak berubah, namun terdapat perubahan dalam masyarakat manusia yang mengharuskan adanya perubahan dalam hukum.

Penerimaan atas ketidakberubahan sebagai suatu kenyataan maupun sebagai suatu ideal barangkali dapat dilacak kembali pada pengalaman kehidupan pengembara- 
an orang Arab. Pengalaman tersebut telah mengakibatkan munculnya anggapan bahwa keamanan diperoleh dengan mengikuti "jalan yang ditempuh" (Sunnah) nenek moyang (h.11). Sehingga segala sesuatu yang baru patut dicurigai. Bahkan Al-Qur'an sendiri (46: 9) menurut interpretasi Watt secara cermat menekankan bahwa pengangkatan Muhammad sebagai seorang Nabi bukanlah suatu hal baru, tetapi ia datang setelah sederetan panjang nabi dan Rasul.

Selain fenomena potret diri tradisional Islam berupa penolakan terhadap pembaharuan atau perubahan, terdapat suatu pengertian bahwa keseluruhan sejarah Islam dapat dikatakan telah diidealisasikan oleh kaum tradisionalis. Kondisi ini berimplikasi besar bahwa masyarakat terlalu dihantui oleh impian untuk menciptakan kembali suatu yang telah lama berlalu sehingga gagal melihat dan mengatasi berbagai tantangan dan permasalahan nyata dewasa ini. Kritik Watt terhadap idealisasi Islam awal di atas dimaksudkan untuk membuka kemungkinan bagi kaum Muslimin dewasa ini agar mereka dapat menemukan inspirasi untuk mengatasi berbagai permasalahan masa kini dengan merenungkan Al-Qur'an dan sunnah dengan cara yang lebih bermanfaat untuk "kembali" ke masa lampau.

Pandangan dunia standar dan potret diri Islam tradisional tersebut menurut Watt juga disebabkan oleh lembaga keagamaan yang dibentuk dalam suatu kurun waktu, yang terdiri dari beratus-ratus tahun. Lewat upaya lembaga inilah pandangan dunia tersebut menguasai alam pikiran seluruh kaum Muslimin, yang sampai saat ini masih berupaya mempertahankan dominasinya.

Untuk menghadapi permasalahan-permasalahan masa kini, tetapi tidak meninggalkan seluruh peninggalan peradaban masa lalu yang merujuk kepada Al-Qur'an dan hadits (fundamentalis) maka terdapat suatu garis besar atau kerangka pandangan dunia dan potret diri yang lebih tepat untuk masa kini dan masa-masa yang akan datang seperti yang ditawarkan Watt (h. 256-258), sebagai berikut:

$\Rightarrow$ Al-Qur'an memberikan kebenaran keagamaan dan moral yang diwahyukan oleh Tuhan. Meskipun pada mulanya kebenaran ini disesuaikan dengan kebutuhan-kebutuhan orang Arab abad ke-7, namun sifat-sifat dasarnya memiliki keabsahan yang universal dan berisi petunjuk bagi umat manusia di abad ke-21 dan seterusnya.

$\Rightarrow$ Muhammad adalah seorang nabi agung . dan pemimpin keagamaan.

$\Rightarrow$ Lembaga keagamaan Islam merumuskan suatu pandangan dunia dan potret diri, dan dalam cara semacam ini telah memapankan suatu struktur sosial yang memampukan berjuta-juta manusia mengurangi kehidupan yang memuaslegakan selama berabad-abad. Bahkan pandangan dunia dan potret diri itu perlu diubah dewasa ini, bukan lantaran ketidaksempurnaan yang terkandung di dalamnya karena pada mulanya dirumuskan untuk masa khususnya tersebut, tetapi karena perkembanganperkembangan teknologi dan industri modern, serta perubahan-perubahan dalam struktur sosial mengharuskan adanya pengubahan tersebut.

$\Rightarrow$ Masyarakat Muslim telah memberikan sumbangan penting kepada sejarah umat manusia dengan menciptakan kemantapan sosial dalam sebagian besar belahan dunia, bahkan ketika terdapat pergolakan-pergolakan politik.

$\Rightarrow$ Islam menampilkan suatu versi khas monoteisme Ibrahim, dan dengan demikian memiliki suatu tempat dalam rencana Tuhan bagi penyelamatan umat manusia. Islam mungkin dapat menjadi pengoreksi beberapa praksis Kristen yang berlebihan, dan dapat pula 
bekerja sama dengan bantuan agamaagama lain untuk mewujudkan suatu dunia yang berkeadilan sosial serta penuh kedamaian berdasarkan prinsipprinsip moral yang sehat.

Inilah garis besar suatu potret diri Islam yang lebih tepat dibandingkan potret diri yang didukung kaum tradisionalis, tetapi tidak lebih dari suatu garis besar yang mesti diisj kaum Muslimin sendiri.

\section{Penutup}

Dari beberapa uraian buku ini terlihat jeias bahwa masalah mendasar yang mesti dijawab seluruh kaum Muslimin adalah apakah mereka hendak menjadi bagian dari satu dunia, atau akan mengarunginya sendiri dan hidup dalam dunia mereka sendiri yang semata-mata Islami. Tentunya jelas bahwa mayoritas terbesar ummat Islam ingin mengenyam seluruh kenikmatan dan kemewahan material yang dihasilkan barat, tetapi kebanyakan kaum tradisionalis berpikir bahwa mereka bisa ikut menikmatinya dengan tetap menyekat diri dari aspekaspek lain kebudayaan Barat, yang dipandang merosot dalam dirinya dan merusak masyarakat Islam.
Jadi kaum Muslimin yang menutup matanya dari kejadian-kejadian yang tengah berlangsung di sebagian besar dunia dalam kenyataannya tengah membangun tempat pengasingan untuk diri mereka. Memperhatikan kejadian yang tengah berlangsung di berbagai bagian dunia lain tidak berarti mesti menyetujuinya. Namun kebanyakan kaum tradisional Muslim hampir secara sepenuhnya mengabaikan gerakangerakan keagamaan dan kemanusiaan di luar dunia mereka, serta cenderung memandang keseluruhannya sebagai tidak berharga. Kajian-kajian awal kaum Muslimin tentang agama-agama lain sebagian besarnya dilakukan untuk mencari butirbutir doktrinal yang dapat digolongkan sebagai bidah. Salah satu hal yang secara khusus mesti diperhatikan kaum Muslimin adalah mengkaji agama-agama lain untuk melihat apakah di dalamnya terdapat suatu nilai yang positif. Dengan cara semacam ini, mereka akan menyadari bahwa dunia di luar mereka tidaklah dipenuhi oleh orang-orang yang mesti diperangi, tetapi berisi banyak orang yang dapat diajak bekerja sama dalam mencapai tujuantujuan bersama.

Rahmani Timorita Yulianti 